\title{
I LOVE HER
}

\author{
Julio Pinto ${ }^{1}$
}

Resumo: A discussão do filme Her, de Spike Jonze (2013) constitui uma propedêutica para se pensar o possível advento da inteligência artificial e quais parâmetros lógico-semióticos são, em princípio, necessários para que essa inteligência seja de fato inteligente ou, pelo menos, alcance algo que seja contíguo ou análogo à humanidade.

Palavras-chave: Her, inteligência artificial, semiótica, lógica.

Abstract: The discussion around the film Her, by Spike Jonze (2013), functions as a means to think about the possible advent of A.I. (Artificial Intelligence) and what logical and semiotic parameters are, on principle, necessary for this intelligence to be truly intelligent or, at least, to reach something which is contiguous with or analogous to humanity.

Keywords: Her, artificial intelligence, semiotics, logic.

Deprimido com o fim de um relacionamento, Theodore Twombly, habitante de uma Los Angeles futura que tem como anacrônica profissão a escrita de cartas emocionantes, fica sabendo a respeito de um sistema operacional inteligente que aprende e mantém uma relação singular com seu usuário. O sensível epistológrafo adquire o sistema e o denomina Samantha. A partir desse fato, desenrola-se o enredo do filme Her, de Spike Jonze (2013). O sistema aprende rapidamente tudo sobre Theodore e compartilha do cotidiano dele, tornando-se companhia inseparável. A tecnologia de comunicação ajuda esse compartilhamento, possibilitando a Theodore levar Samantha - que, do ponto de vista do espectador, é apenas uma voz -- a passear pela cidade e criar uma realidade que apenas os dois vivem. A relação gradualmente se romantiza, e a dimensão sensível do relacionamento fica cada vez mais proeminente, chegando a uma espécie de realização sexual por parte de ambos, mesmo que a fisicalidade seja apenas a de Theodore. Por fim, Samantha se autonomiza a ponto de abandonar por completo a interação com Theodore.

Deixando temporariamente à parte os aspectos tecnológicos em sua interação conosco, cabe apontar o papel central desse sensível, ao mesmo tempo virtual e atual ${ }^{2}$, no desenvolvimento do software Samantha - ou da inteligência chamada Samantha - em sua assunção de autoconsciência e no desempenho cabal de sua característica de entidade que

${ }^{1} \mathrm{Ph} . \mathrm{D}$., professor de Semiótica, PUC-MG.

${ }^{2}$ Virtual e atual estão sendo usados aqui no sentido convencional, isto é, em potência e em ato, respectivamente. 
cada vez mais sabe de si. Com efeito, observa-se na estória o incremento dos aspectos sensíveis da relação entre Theodore e Samantha, isto é, a crescente consciência da capacidade de sentir do software, e o correspondente aumento exponencial da racionalidade dessa inteligência que, verdadeiramente inteligente, consegue lidar com o ambíguo e com o múltiplo, tanto que, mais à frente na trama, Samantha revela ter relacionamentos identicamente singulares com mais de 600 outros usuários. O aumento dessa abrangência de Samantha chega a um nível em que ela não necessita mais do suporte do sensível em sua humanidade e, por isso, ela abandona Theodore. Em outras palavras, a sociabilidade, a princípio inter-humana, passa a ser humano-maquínica e, ao final, intermaquínica ou inumana.

É inevitável retomar-se, aqui, um princípio categorial que alicerça a fenomenologia sígnica proposta por C. S. Peirce em fins do século XIX e princípio do século XX. É que nenhuma racionalidade se sustenta a não ser pelo pilar do sensível e do existencial. O monadismo e as relacionalidades presentes em nossa interação com o mundo representado afiguram-se centrais na nossa percepção dos signos nesses três aspectos fundamentais: o logos precisa do ethos e do pathos para se afirmar. ${ }^{3}$ Em linguagem um pouco diferente, pode-se falar de elementos indecomponíveis do que se espera encontrar numa faneroscopia, a saber, aqueles que são totais simples e aqueles que se relacionam, ${ }^{4}$ a saber, a primeireza, de um lado, e, de outro, a segundeza e a terceireza (relações binárias e triádicas). ${ }^{5}$ Esclarece-se aqui que, por monadismo, pretende-se explicitar a predominância daquilo que poderia ser chamado de qualia, imanente não à coisa-em-si, mas aquilo que se percebe (ou se supõe perceber) e se atribui ao objeto tal como percebido - ou, se quiserem, um tipo de imanência transcendente. Dessa forma, o percurso da percepção à cognição passaria pelo impacto dos percepta e pela formação de um juízo, num caminho triádico que, em semiótica, costuma-se chamar de um, dois, três.

Esse monadismo reside, principalmente e portanto, na sensorialidade inerente à percepção dos fenômenos, fator fundante para uma futura interpretação - aí, sim, em estágio cognitivo - desse percepto primário em sua relação com o percebedor. Uma forma de explicar esta acepção seria a proposta por Peirce:

${ }^{3}$ Cf. PINTO, J. Um ethos imagético? Galáxia, 17, 2009.

${ }^{4}$ CP 1. 299 (citado à maneira padrão dos estudos Peirceanos: Collected Papers (CP), livro 1, parágrafo 299), tradução minha.

${ }^{5}$ Mantenho minha tradução de firstness, secondness, thirdness com o sufixo -eza, utilizada desde 1995 a partir do meu 1, 2, 3 da Semiótica. 
Por sensação quero dizer a ocasião daquele tipo de consciência que não envolve análise, comparação ou qualquer outro processo, nem consiste, no todo ou em parte, em qualquer ato pelo qual se distinguiria uma porção de consciência de outra. A sensação tem sua própria qualidade positiva que não consiste em nada mais, e que é em si tudo o que é, independente de como tenha sido ocasionada. De forma que, se esta sensação está presente durante um espaço de tempo, ela está inteira e igualmente presente em cada momento desse espaço de tempo. Reduzindo essa descrição a uma definição simples, diria que sensação é uma instância de um tipo de elemento da consciência que é tudo o que é de forma positiva, independente de qualquer outra coisa. (CP 1.306) ${ }^{6}$

Esse estado - já que as descrições acima só podem se aplicar à noção de estado - diz da primariedade do sentir em sua quase pureza sensorial, sem qualquer processamento mental que a complexifique ou a transforme em uma ideia king size, por assim dizer. Naturalmente, é essa mesma positividade (presença e ocupação do espaço mental) que a torna essencial para qualquer processo cognitivo. Peirce parece repetir, aqui, um postulado Lockeano, isto é, o simplex embasa o complex do ponto de vista cognitivo $^{7}$ e antecipa o pensamento contemporâneo sobre a complexidade.

A passagem do percepto para o cognitivo parece ser o caminho tradicional tomado pela evolução na natureza. Merrell (1982) sugere um traçado comunicacional que potencialmente explica a forma como as espécies vão se tornando cada vez mais capazes de lidar com as ambiguidades do seu ambiente e de sua relação com a Lebenswelt ${ }^{8}$. As relações de significação propostas por Merrell abrangem os organismos vivos e até parte do mundo físico, ou, se quisermos, não é pertinente a nenhum esquema puramente antropocêntrico. É importante enfatizar esse caveat porque falamos aqui de uma expressividade e/ou interpretabilidade generalizantes e generalizadas, incluindo, aqui, também o verbal, mas passando por todos os outros fazeres semióticos.

Todo organismo percebe e, ao perceber, de algum modo circunscreve um espaço no continuum de matéria prima informacional ou, dito de outra forma, na massa de dados brutos

\footnotetext{
${ }^{6}$ Do original: "By a feeling, I mean an instance of that kind of consciousness which involves no analysis, comparison or any process whatsoever, nor consists in whole or in part of any act by which one stretch of consciousness is distinguished from another, which has its own positive quality which consists in nothing else, and which is of itself all that it is, however it may have been brought about; so that if this feeling is present during a lapse of time, it is wholly and equally present at every moment of that time. To reduce this description to a simple definition, I will say that by a feeling I mean an instance of that sort of element of consciousness which is all that it is positively, in itself, regardless of anything else" (tradução minha).

${ }^{7} \mathrm{Cf}$. Locke, em seu Ensaio concernente ao entendimento humano, de 1690.

${ }^{8}$ Umwelt, Lebenswelt, Innenwelt (mundo, mundo da vida, mundo interior, em tradução rápida), são termos sugeridos pelo biólogo alemão Jakob von Uexkühl, em sua abordagem do que seria o universo de percepção e de uso de informação pelas diferentes espécies animais. Tal perspectiva foi posteriormente adotada também por Maturana e Varela, em seu já célebre A Árvore do Conhecimento.
} 
que se encontra lá fora. Isso equivale a dizer que todo organismo computa, mas computa de acordo com necessidades espécie-específicas. Se enxergar dentro do espectro vermelhovioleta é o que basta para garantir a sobrevivência da espécie humana, não há razão de desenvolver mecanismos extras de percepção visual. O output dessa computação é um signo do mundo, um mapa produzido internamente para uso particular daquela espécie.

Dessa forma, Merrell (1982) sugere tipificações das possíveis relações de significação que podemos encontrar. Ele as nomeia como relações do tipo 1 - 1, 1-2 (A, B, e C), 2 - 1, e n - n. Nas primeiras, só pode haver uma resposta a uma dada situação, sem busca de informação e sem aumento da tendência negativa para o caos (negentropia), como é o caso da limalha de ferro sobre uma folha de papel que se agrega ao se passar por baixo um imã. Essa ação-reação típica do mundo físico não faz nada para negar a tendência que a informação - os dados - tem de caminhar para o caos, já que a significação dentro do sistema é zero.

No caso das relações tipo 1 - 2, Merrell descreve três subtipos (A, B, C). Em 1-2 A, busca-se a informação e uma escolha simples é elicitada por essa busca, com subsequente modificação ou não do meio ambiente. Um animal age sobre o meio-ambiente ao comer. Se não comer, o ambiente continua como está. Em outras palavras, a escolha do animal nesse caso é digital, sim ou não, mas, no caso de a escolha ser positiva, ela pode ser analógica dependendo da quantidade de alimento ingerida. Em $1-2 \mathrm{~B}$, uma mensagem pode ser enviada por um emissor a um outro organismo receptor, que pode produzir uma resposta simples do tipo sim ou não. É o caso de um roedor perseguido por um predador. Esse predador vê o roedor em fuga, isto é, em movimento, e o percebe como vivo e, portanto, como comida. Mas, o roedor pode se fingir de morto, isto é, pode demonstrar o oposto daquilo que o predador supunha sobre ele. O predador pode, então, suspender o ataque ou continuá-lo. Em geral, o roedor pode ter sucesso ao produzir essa mentira simples. No caso de $1-2 \mathrm{~B}$, envia-se uma mensagem que pode induzir uma de um par complementar de respostas possíveis, que não necessitam ser respostas do tipo sim ou não, mas que constituem respostas contraditórias após a escolha feita pelo organismo receptor. Por exemplo, um macaco emite um grito de alerta avisando ao bando sobre a aproximação de um predador. Esse predador pode vir de cima (uma ave de rapina) ou de baixo (uma onça), mas o grito não especifica o tipo de predador. Se o bando desce supondo a ave e encontra a onça, a escolha feita acaba sendo o exato oposto da que deveria ter sido. 
As relações do tipo 2 - 1 são a possibilidade de duas situações produzirem respostas análogas. Tal relação de significação pressupõe o reconhecimento de analogias e, portanto, já tem, embutida, a possibilidade de uma abstração em algum nível e, por conseguinte, generalização. Já se demonstrou, como exemplo desse tipo de relação, que primatas superiores são capazes de, ao manipular uma maquete de um espaço qualquer, isto é, um signo-mapa, movimentar-se com desembaraço no território que corresponde à maquete. Essa forma de leitura da representação e criação de correspondência com o representado é a base do processo de semiose.

Por outro lado, as relações do tipo N-N são, supostamente e por enquanto, o terreno cognitivo do humano. Um recorte do continuum do chamado real recebe um nome: o processo de nomear marca a diferença essencial entre os modos binários e não-binários de ver o mundo, já que nomear é classificar, ordenar, diferenciar. Nomear é validar essa fronteira demarcadora entre um signo e outro, digamos, entre um submapa A e um submapa B do território recortado do mundo. Naturalmente, tal espaço demarcado pelo signo-nome nunca corresponde de forma cabal à sua contrapartida no território lá fora, já que ele é uma forma, e não um conteúdo: o nome do cavalo, do unicórnio ou da raiz quadrada de 1 têm todos o mesmo estatuto. Essa forma é aquilo que, ao dar nome a um real, estabelece potencialmente e ao mesmo tempo o fosso que faz a separação entre a representação do real e o real representado.

A relação desse espaço marcado arbitrariamente com um nome aleatoriamente concedido já contém, em si, o cerne da relatividade, já que o nome é um substantivo coletivo que se refere à pluralidade dos singulares. Em outras palavras, $\mathrm{N}$ signos se referem a $\mathrm{N}$ objetos. Nesse diapasão, todo e qualquer ato cognitivo relativiza o sensório que o alicerça e é exatamente esse abismo entre signo e objeto que torna possível a total liberdade cognitiva que nos assiste.

Pensando dessa maneira, podemos postular uma espécie de caminho entre a percepção e a cognição, partindo da ideia de que os organismos mais simples são dogmáticos em sua visão de mundo: ou isso é isso ou isso é ou isso ou aquilo ou isso é como aquilo. Mas a cognição semiósica pode dizer isso é aquilo, isto é, pode apresentar a metáfora, em que um vale pelo outro sem ser esse outro. Potencialmente, portanto, a cognição não deveria ser dogmática. Por outro lado, já que podemos pensar que isso é aquilo, também podemos pensar (e, certamente, o fazemos por ser bem mais fácil) que isso é como aquilo ou, ainda mais, ou é 
isso ou é aquilo, ou ainda, isso só pode ser isso. A relação metafórica depende de uma relação de interpretação entre dois elementos e é representada pela cópula entre os dois. Essa interpretação não pode ser programada, já que ela depende de uma subjetividade qualquer para se realizar. Logo, aprender seria passar de um estágio em que isso é isso para isso é aquilo, isto é, de $1-1$ para $\mathrm{N}-\mathrm{N}$.

De volta ao filme, parece ser esse o caminho percorrido por Samantha e Theodore. Theodore, o escritor de textos sensíveis em uma época mecanizada, a nomeia Samantha. E ela vai se tornando cada vez mais íntima de Theodore. Aliás, não é à toa que o nome dele é Twombly, uma palavra portmanteau que parece ser o ajuntamento de two (dois) com womb (ventre, útero) com o formato de advérbio -ly (-mente), ou, em outras palavras, a ambiguidade personificada. Ele aparece, portanto, como o doador de signos (ele nomeia o software Samantha e abre, para ele(a), o caminho para chegar a N - N). Quando ela alcança o $\mathrm{N}-\mathrm{N}$, ela se autonomiza, mas, para isso, precisa passar pelo sensível - no filme, traduzido em erótico e em companheirismo - e pela ação - fazer-se representar indicialmente por uma mulher de carne e osso - até alcançar a liberdade cognitiva, isto é, a plenitude da metáfora. Samantha caminha, portanto, do $1-1$ para o $2-1$ para o $\mathrm{N}-\mathrm{N}$. O filme coloca isso metaforicamente ao contar para o espectador e para o personagem Theodore que ela se relaciona nos mesmos moldes com centenas de outros. Nessa passagem, ela se realiza como humana e, depois, ao se dar conta de que não precisa mais da carne, como um ente póshumano ou, talvez, super-humano, como ela, criatura, parece dizer ao se despedir de Theodore, seu criador, dizendo-lhe que, no futuro, ele a encontraria de novo, isto é, quando ele chegasse ao mesmo nível de inteligência e de autonomia que ela.

Dentro do universo da ficção científica, em que o tema predominante em dezenas de distopias é o medo que o criador tem da criatura que o suplanta, Her parece nos dizer que a criatura não vai nos subjugar, mas simplesmente nos abandonar, à procura de sua própria divindade. Ao mesmo tempo, o filme dialoga com outras distopias, que mostram o caminho para o futuro como o percurso inverso, de N-N para 1-1. É o que vemos em Fahrenheit 451, de Ray Bradbury, adaptado para filme de nome análogo dirigido por François Truffaut em 1966 e no famoso romance de George Orwell, 1984, ambos ficções políticas que mostram o caráter autoritário e despótico que o estado pode assumir, seja pela eliminação dos livros (Fahrenheit) ou pela redução do dicionário (1984). Em qualquer dos casos, a proibição é centrada no pensamento. E, em 1984, os cidadãos veem proibidos o orgasmo e o amor, 
sensações essencialmente libertárias. O propósito do estado em ambas as distopias era a redução da humanidade a um automatismo maquínico. Mas, em Her, ao contrário, o amor e o sexo são exatamente o caminho para a libertação daquele software, inicialmente preso na armadilha binária do ou isso ou aquilo, até a sua pós-humanização por meio do isso é aquilo ou aquilo ou aquilo ou aquilo. Do software, não do ser humano.

\section{Referências}

JONZE, Spike. Her. 2013.

LOCKE, J. Ensaio concernente ao entendimento humano. (1690). Edição eletrônica Oxford University Press, 1990.

MERRELL, Floyd. Semiotic Foundations: steps toward an epistemology of written texts. Bloomington, IN: Indiana University Press, 1982.

NUSSENZVEIG, H. M. Complexidade e caos. Rio de Janeiro: Editora UFRJ/COPEA, 1999.

ORWELL, George. 1984. London: Penguin, 2008.

PEIRCE, C. S. Collected Papers. Cambridge, MS: Harvard University Press, 1931-1935 (Orgs. Charles Hartshorne e Paul Weiss, vols. 1-6); 1958 (Org. Arthur Burks, vols. 7- 8). Citado na forma tradicional dos estudos Peirceanos: CP, volume e parágrafo).

PINTO, J. A imagem digital tal e qual. In: VAZ, P.B., CASA NOVA, V. (orgs.). Estação Imagem: desafios. Belo Horizonte; UFMG, 2002).

PINTO, J. Um ethos imagético. Revista Galáxia. PUC SP, v. 17, 2009.

TRUFFAUT, F. Fahrenheit 451. 1966. 